\title{
Phonology of Igbo Compound Place Names
}

\author{
IFEOMA EMMANUELA UDOYE \\ Chukwuemeka Odumegwu Ojukwu University, Igbariam Campus, Nigeria.
}

\begin{abstract}
This paper presents a phonological study of Igbo language toponyms using Allen's (1978) Strong Boundary Condition as a theoretical base. The basis of the study is to prove that strong boundary condition for compounds can be applied to Igbo place names in order to further endorse its universality. The paper posits that tonal changes and regressive assimilation are common features among nonproductive compounds while productive compounds are insensitive to phonological changes.
\end{abstract}

Keywords: Phonology, Igbo, Compounds, Place names, Tones

\section{Introduction}

The Igbo nation constitutes of five SouthEastern states in Nigeria. These are Anambra, Enugu, Ebonyi, Abia, Imo and some parts of Delta and Rivers States. Igbo belongs to the West Benue-Congo sub-family of the ProtoBenue-Congo language family with about eighteen million speakers.

In this paper, the researcher is interested in the phonology of Igbo compound place names.

Although, attempts have been made to discuss names among the Igbo people, the studies have only focused on personal names generally and not on tones of Igbo compound names (see Udoye, 2018). The present work is different from the previous ones because whereas the earlier works focused on Igbo personal names in general, the present work seeks to understand how tones function in compound toponyms using Allen's 1978 theory, Strong boundary condition for compounds. It is argued here that tonal change in compound toponyms occur at word boundaries and word final positions in compound place names.

\section{Overview of Igbo Sound System}

The tonal system of Igbo is the register - tone type in which sequences of high tones may continue a proceeding high tone level or step down to a new level, (Emenanjo, 2015). Although, high and low tones can occur in all positions (- initial, medial and final) in Igbo language tonal system, no word has been found to begin with a down step tone. The tonal patterns found in Igbo are:
HH 'high high'
LH 'low high'
HL 'high low'
LL 'low low'
HS 'high down-step'

\section{Example:}

$\mathrm{HH}$

ákwá

$\mathrm{HL}$ 'cry'

ákwà

LH

$$
\text { 'cloth' }
$$

LL àkwá

àkwà 


\subsection{Vowel Harmony}

Vowel Harmony is the system whereby in many languages vowels divide themselves into two sets (+ATR and - ATR). The first set (+ATR) is produced when the root of the tongue is advanced or widened and they are usually written without dots, while the second set (ATR) is produced when the root of the tongue is narrowed:

$\begin{array}{ll}{[+ \text { ATR] }} \\ \mathrm{i} & \mathrm{u} \\ \mathrm{e} & \mathrm{o}\end{array}$

$\begin{array}{ll}\text { [-ATR] } \\ \text { I } \\ \text { a } & \text { ụ }\end{array}$

\subsection{Compounding}

According to Udoye (2018), compounding occurs when two or more words are joined together to form a word. She observes that nominal compound personal names are the most productive of all Igbo personal names. Taiwo (2009) opines that in deriving compounds in Yoruba language, some phonological processes take place such as tonal displacement or replacement and vowel elision. Similarly, Okoye 2016) notes that Etulo compound words undergo both vowel and tonal elision.

\section{Theoretical Framework}

Allen's 1978 theory, the Strong Boundary condition for compound is the most suitable theory for the study. It gives explicit recognition to compounds in English and Welsh languages. Allen's theory is contained in Morphological investigation and later applied to the Igbo language by Anagbogu (1995). Allen 1978 stated that the strong boundary condition does not apply to non-productive compounds but only to true compounds because non-productive compounds allow phonological rules to operate across word boundaries. The reason for allowing phonological rules to operate across boundaries is because of weak internal boundaries which lead to phonological change. But for true compounds or productive primary compounds as shown by Anagbogu (1995), the internal boundaries are strong and prohibit phonological rules operating across boundaries. While Anagbogu (1995) used Igbo personal names in general to discuss the universality of this theory, the present work used place names found in Anambra East and Awka South in Anambra State, Nigeria to discuss the theory.

\section{Literature Review}

Udoye (2018) studies senselessness of Awka place names. She discovers that history, etymology and semantics operate in Igbo place names and indeed Africa languages and place names in general. Udoye maintains that African place names as well as their personal names are meaningful (as against the English senseless proper names discussed in Udoye 2018). The most significant aspect of the study is the indepth analysis of commemorative, cultural, incident and calendar names to prove that Igbo names are connotative and not denotative as claimed by earlier western scholars. The present study focuses on the phonology of place names and not on how meaningful Igbo names are.

Okoye and Osuagwu (2017) investigate the similarities and differences of Igbo and Etulo tones. They discover that Igbo tonal change occurs on the third person pronoun and it is used to differentiate declarative sentences from interrogative sentences. In both Igbo and Etulo languages, nouns in associative construction change their inherent tones. The study has enriched the researcher's knowledge on tones in general. It is similar to the present work because it considers the functions of tones while the present study focuses on how compound place names change their tones depending on their places of occurrence.

Obianika (2014) examines tone in Abankaleke Igbo. She discovers that there is a feature of the high rising tone in Izii and Ezaa which is not phonetic and is not found in other Igbo dialects. The work is different from the present work because the present work looks at how tones cause phonological change in compound place names.

Obiamalu (2013) examines the role of tone in Igbo negation. He discovers that high tone plays a vital role in negation. Obiamalu cited examples using names such as: íféányi-chúkwú 
(nothing surpasses God), $A ́-m \bar{a}-\dot{n} n a ̀$ (father is not known) to indicate that high tone on the agreement prefixes give the names their negative meaning. Interrogative and non-interrogative names could be differentiated by a low tone in the subject noun as shown below:

Ife - a- ny̌̀ - chukwu

Thing - Agr.NEG-surpass God

'nothing surpasses God'

$\mathrm{A}-$ mā nnà

AGR - NEG-know - father

'father is not known'

Although the present work is based on Igbo tones, it differs from Obiamalu (2013) work because the former considers Igbo tones in negation but the present study considers how Igbo tones function in compound place names with the aim of contributing to the onomastic study of Igbo toponymy.

\section{Data Presentation and Analysis}

Here, as elsewhere, the researcher followed the widespread tone-marking convention leaving high tones unmarked, marking low tones with a grave accent / / and downstep with a macron /-/ (cf. Emenanjo 2015, Anagbogu 1995). Anagbogu (1995:250) classified Igbo nominal compounds into three types:

- Those that are characterized by tonal changes only

- Those that have undergone regressive assimilation and tonal change and

- Those that are insensitive to phonological processes.

The same classification is applicable to Igbo toponyms that have the Igbo compound structure; because indeed, most toponyms in my data are compound nouns; and most examples in the data are examples of genitival or associative constructions, and fit into the above three categories.

\subsection{Toponyms that are Characterized by Tonal Changes Only:}

Consider the following examples:
Inherent Tones of N1 and N2 Tones after $\mathrm{N} 1+\mathrm{N} 2$ have Undergone the Morphological Processes of

\section{Compounding Processes of Compounding} Ụmụ ọ̀nyịma

$\mathrm{H}$ L L L H children onyima

$$
\rightarrow \quad \text { Ưmụ̄ ọ̀nyịma }
$$$$
\rightarrow \quad \mathrm{H} \mathrm{H} \text { ! + L L H }
$$$$
\text { 'onyima's children' }
$$

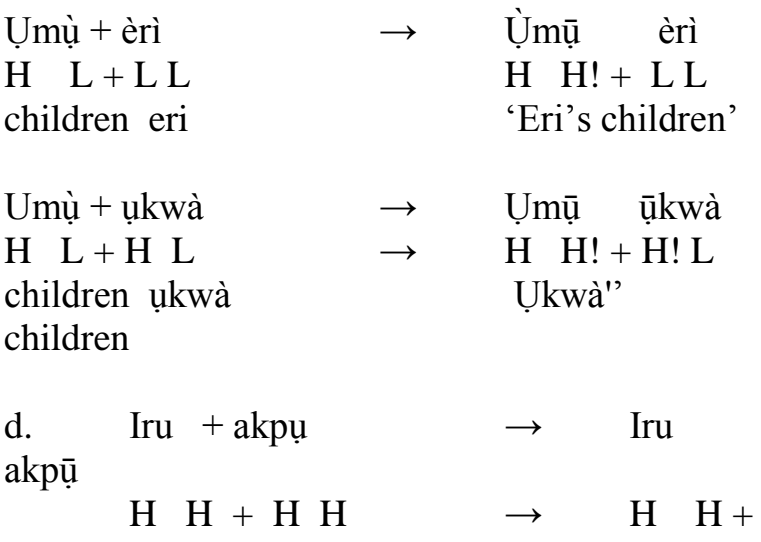

$\mathrm{H} \mathrm{H}$ !

Face cassava cassava's face

\begin{tabular}{|c|c|}
\hline $\begin{array}{l}\text { Iru }+ \text { echi } \\
\mathrm{H} \mathrm{H} \text { H } \mathrm{H} \rightarrow \\
\text { face tomorrow } \\
\text { tomorrow }\end{array}$ & 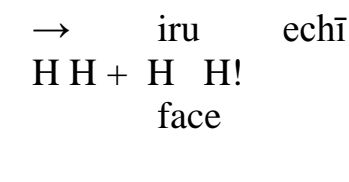 \\
\hline + òbhu & ama ōbhū \\
\hline $\mathrm{L} \quad \mathrm{H}$ & L L H! H! \\
\hline
\end{tabular}

In the examples above which have undergone tone rules, it is observed that phonological processes take place mostly at the boundaries between compound members, affecting the final vowel of $\mathrm{N}_{1}$ which are raised from low to down step in (a), (b), (c) and in the final vowels of (d), (e), and (f).

\subsection{Some Toponyms Undergo Both Tonal Change and Regressive Assimilation Processes:}

Anagbogu (1995) observes that $n w a$ 'child' in Igbo personal names appears to be the most productive for regressive assimilation and tonal change as shown below: 


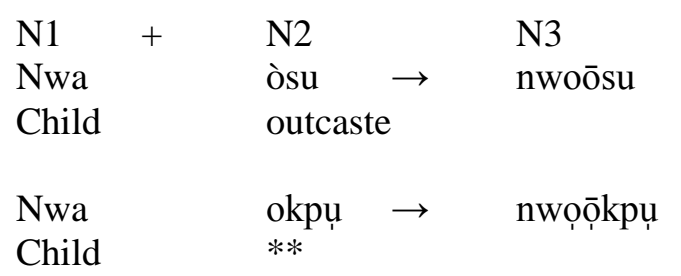

Similarly, in Anambra place names, prefixes umu and ama behave like nwa as shown below.

\begin{tabular}{|c|c|c|}
\hline $\begin{array}{ll}\text { Ummụ̀ } & \text { ike } \\
\text { H-L } & \text { H-H }\end{array}$ & $\rightarrow$ & $\begin{array}{l}\text { Ụmī } \quad \text { īkē } \\
\mathrm{H}--\mathrm{H} ! \\
\mathrm{H} ! \mathrm{H} !\end{array}$ \\
\hline $\begin{array}{l}\text { Ama ùdo } \\
\mathrm{H} \quad \mathrm{H} \text { L H }\end{array}$ & $\rightarrow$ & $\begin{array}{c}\text { udō } \\
\text { H-H! }\end{array}$ \\
\hline $\begin{array}{l}\text { Ưmụ ékètè } \\
\dot{H} \quad \text { L H L L }\end{array}$ & $\rightarrow$ & $\begin{array}{l}\text { umē èkètè } \\
\mathrm{H} H ! \mathrm{H} ! \mathrm{L} L\end{array}$ \\
\hline
\end{tabular}

The second vowels of $\mathrm{N}_{2}$ in (a) and (b) which were inherently high toned are reduced to down step; the initial vowels of $\mathrm{N}_{2}$ in (a) and (c) are reduced from high to down step respectively and the down stepped tone is extended to the final vowels of $\mathrm{N}_{2}$ in (a) and (b), in the three examples provided above, the regressive assimilation rules seem to have operated changing the final vowel of $\mathrm{N}_{1}$ in (a) from ' $\mathrm{u}$ ' to ' $i$ ', and in (b) from ' $a$ ' to ' $u$ ' and in (c) from ' $u$ ' to 'e' respectively. From the examples above, it is obvious that the internal boundaries collapsed and the compounds which were once independent words became lexicalized and lost their semantic compositionality.

\subsection{Toponym Compounds that are Insensitive to Phonological Changes}

Compounds that belong to this category are true compounds that stick to SBC rules. The category of toponym compounds below retains their inherent tones after undergoing the morphological process of compounding.

$\begin{array}{lllll}\text { Iru } & \text { agụ } & \rightarrow & \text { iru } & \text { aḡ̣̣ } \\ \text { H H } & \text { H H! } & & \text { H H } & \text { H H! } \\ & & & & \\ \text { Ama } & \text { agụ } & & \text { ama } & \text { agū } \\ \text { H H H H! } & & \text { H H } & \text { H H! }\end{array}$

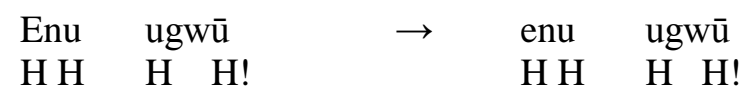

It is pertinent to observe that compound toponyms behave phonologically like Igbo noun compounds described in Anagbogu (1995).

\section{Conclusion}

From the foregoing, the researcher has established that the rules of the strong boundary condition for compounds is truly language universal and function in Igbo personal names as well as place names. Non-productive compounds are affected by tonal changes and regressive assimilation while true compound place names are insensitive to phonological changes because of their strong internal strong boundaries. In conclusion, the study is a significant one because it has been established that the theory is universal.

\section{References}

Allen, M. (1977). Morphological Investigation. Unpublished Doctoral Dissertation. The University of Connecticut.

Anagbogu, P. (1995). The Strong Boundary Condition for Compounds: The Igbo Perspective. In N. Emenanjo \& O. Ndimele (Eds.), Issues in African Languages and Linguistics: Essays in Honour of Kay Williamson (pp.246 -257). Aba: National Institute for Nigerian Languages.

Obiamalu, G. (2013). On the Role of Tone in Igbo Negation. Journal West African Languages, $\mathrm{xl}(2), 13-26$.

Obianika, C. (2014). Tone in Abankaleke Igbo: An Acoustic Analysis. Global Journal of Arts, Humanities and Social Sciences, 2 (6), 11 28.

Okoye, N. \& Osuagwu, E. (2017). Tone in Igbo and Etulo: A comparison. Igbo Language Studies, 1, 99-111.

Udoye, I. (2018). Senselessness of Proper Names: A Study of Awka Toponyms Southeastern Nigeria. Papers in English and Linguistics, 19 (364), 369 - 394.

Udoye, I. (2018). A Linguistic Appraisal of Igbo Anthroponyms. Journal of Lexicography and Terminology, 2 (1) 1 -19. 